УДК [(371.134:371.2)+613] (043.3)

DOI:

Раїса Пріма, доктор педагогічних наук, професор, завідувач кафедри теорії і методики початкової освіти Волинського національного університету імені Лесі Українки Олена Цибульська, здобувач кафедри теорії і методики початкової освіти Волинського національного університету імені Лесі Українки; викладач ВКНЗ “Володимир-Волинський фаховий педагогічний коледж імені А. Ю. Кримського”

\title{
КОМПОНЕНТНО-СТРУКТУРНИЙ АНАЛІЗ ФЕНОМЕНУ "ГОТОВНІСТЬ МАЙБУТНЬОГО ВЧИТЕЛЯ ПОЧАТКОВОЇ ШКОЛИ ДО ВИХОВАННЯ КУЛЬТУРИ ЗДОРОВ'ЯЗБЕРЕЖЕННЯ МОЛОДШИХ ШКОЛЯРІВ”
}

Актуалізація готовності майбутнього вчителя початкової школи до виховання у молодших школярів культури здоров'язбереження розглядається у контексті иілісної професійної підготовки студентів як цілеспрямований, організаційний прочес включення майбутніх педагогів у активну здоров'язбережувальну діяльність; інтегроване утворення особистості; вміння і навички, необхідні для збереження, зміцнення сприяння здоров'ю; психофізіологічний стан майбутнього педагога. Виокремлено ключові компоненти готовності майбутнього вчителя початкової школи до виховання у молодших школярів культури здоров'язбереження: мотиваційно-особистісний, когнітивний, операційно-діяльнісний та проаналізовано окремі аспекти їх характеристики.

Ключові слова: готовність майбутнього вчителя до виховання культури здоров'язбереження; виховання; компоненти; культура здоров 'язбереження; молодший школяр.

$\operatorname{Iim} .15$.

Raisa Prima, Doctor of Sciences (Pedagogy), Professor, Head of the Theories and Methods of Primary Education Department, Volyn Lesya Ukrayinka National University

Olena Tsybulska, Applicant of the Theories and Methods of Primary Education Department, Volyn Lesya Ukrayinka National University,

Lecturer "Volodymyr-Volynskiy Professional Pedagogical College named after A. Yu. Krymskiy"

\section{COMPONENT-STRUCTURALANALYSIS OF THE PHENOMENON "READYNESS OF THE FUTURE PRIMARY SCHOOL TEACHER FOR EDUCATION OF THE CULTURE OF HEALTH CARE OF YOUNG PEOPLE"}

The actualization of the readiness of the future primary school teacher to educate junior students in the culture of health care is considered in the context of holistic training as a system of theoretically sound and applied knowledge of students about the essence of the culture of health care; purposeful, organizational process, which is characterized by the inclusion of future teachers in active health care activities; integrated personality education; skills and abilities necessary to maintain, strengthen and promote health; psychophysiological state of the future teacher, which characterizes the positive motivation, self-regulation of his behavior, aimed at the interaction of spiritual, physical, mental and social aspects of health, values to their own health and the health of students, awareness of personal responsibility. In the field of structural-component analysis, the key components of the readiness of future primary school teachers to educate junior students in the culture of health: motivational-personal, cognitive, operational-activity and analyzed some aspects of their characteristics. Motivational and personal component of readiness is the basis of training of future primary school teachers in psychological, pedagogical, cognitive and personal spheres, which accumulates value-semantic self-determination of personality, motivationalvalue attitude to one's own health and health-preserving professional-pedagogical activity, an activation sphere of personality. The cognitive component reflects the specifics of health-preserving competence of the future primary school teacher, which is based on the system of psychological-pedagogical, subject and special knowledge, general methodical and special methodical knowledge, the students' understanding of the importance of educating junior schoolchildren in health culture. The operational component enables direct solution of theoretical and practical problems in the field of readiness of the future primary school teacher for health-preserving professional activity aimed at educating the culture of health care of junior schoolchildren.

Keywords: readiness of the future teacher to cultivate a culture of health care; an education; components; health culture; junior high school student.

остановка проблеми у загальному вигляді та ії̈ зв'язок із важливими науковими чи практичними завданнями. У сучасних умовах життєдіяльності суспільства проблема збереження здоров'я особистості та суспільства загалом набуває 


\section{КОМПОНЕНТНО-СТРУКТУРНИЙ АНАЛІЗ ФЕНОМЕНУ "ГОТОВНІСТЬ МАЙБУТНЬОГО ВЧИТЕЛЯ ПОЧАТКОВОЇ ШКОЛИ ДО ВИХОВАННЯ КУЛЬТУРИ ЗДОРОВ'ЯЗБЕРЕЖЕННЯ МОЛОДШИХ ШКОЛЯРІВ”}

першочергового значення. Ситуація пандемії COVID - 19, яка виникла в усьому світі, вносить багато суттєвих змін і потребує осмислення низки проблем, які стосуються здоров'язбереження. Досвід пандемії показав, що фактор здоров'я може відігравати вирішальну роль у розвитку економіки, політики, культури, освіти та інших сферах. Всесвітня пандемія висвітлила безліч проблем, що виникли на тлі порушення здоров'язбереження суспільства. У цих умовах відбувається переоцінка цінностей, переосмислення пріоритетів, отже, особливого значення набувають цінності життя, здоров'я, формування культури здоров'язбереження особистості.

Низкою вітчизняних нормативних документів (Указ президента Про національну стратегію 3 оздоровчої рухової активності в Україні на період до 2025 р. "Рухова активність - здоровий спосіб життя - здорова нація" (2016), Закон України “Про охорону дитинства" (2001), Національна доктрина розвитку освіти (2002), Державна національна програма “Освіта. Україна XXI ст.”, “Концепція формування позитивної мотивації на здоровий спосіб життя у дітей та молоді" (2004)), визначено завдання щодо збереження здоров'я дітей, акцентується на переході до гнучкої, динамічної ступеневої системи підготовки педагогіввихователів, здатних забезпечувати становлення й розвиток фізично та морально здорової особистості дитини. Розв'язати це вкрай складне завдання зможе тільки спеціально підготовлений учитель-професіонал, передусім учитель початкової школи, який, відповідно до специфіки педагогічної діяльності, має застосувати комплекс освітніх та виховних ресурсів здоров'язбережувальної взаємодії у початковій ланці освіти з метою цілісного розв'язання проблеми збереження i зміцнення фізичного, духовного та соціального здоров'я учнів, формування їхньої здоров'язбережувальної компетентності, культури здоров'язбереження. При цьому підготовка майбутніх учителів початкової школи до виховання у молодших школярів культури здоров'язбереження покликана сприяти розв'язанню пріоритетних завдань системи освіти, одним із яких $\epsilon$ “виховання людини в дусі відповідального ставлення до власного здоров'я та здоров'я оточуючих як до найвищої індивідуальної і суспільної цінності” [10].

Аналіз основних досліджень і публікацій, в яких започатковано розв'язання даної проблеми. Серед досліджень, які репрезентують способи реалізації здоров'язбережувальної стратегії у процесі підготовки майбутніх педагогів, виокремлюємо наукові розвідки О. Баштовенко
[1], Н. Бєлікової [2], С. Бобровник, М. Божик, Н. Денисенко, П. Джуринського, Н. Карапузової, А. Петрова та ін. На необхідності запровадження здоров'язбережувального виховання узагальноосвітніх закладах і формування у дітей, підлітків і молоді культури здоров'я, ціннісного ставлення до здоров'я, здорового способу життя наголошується у працях сучасних дослідників Т. Бережної, В. Горащук, В. Оржеховської, А. Циплюк та інших. Науково вартісними вважаємо різноаспектні дослідження (О. Бельорін-Еррера, С. Дудко, Н. Лісневська, Н. Левінець та ін.), пов'язані зі створенням та організацією здоров'язбережувального (здоров'я орієнтованого) середовища у різних закладах освіти. У колі наукових інтересів вітчизнянихучених (О. Бондаренко, Є. Єфімова, В. Коваленко, О. Марків, Г. Остапенко, А. Петрова та ін.) представлені можливості здоров'язбережувальних технологій в удосконаленні системи професійної підготовки майбутніх фахівців. Окремі аспекти заявленої проблеми висвітлено у працях Т. Бойченко, В. Войтенко, М. Гриньової та інших. Водночас питання формування готовності майбутніх учителів початкової школи до виховання у молодших школярів культури здоров'язбереження залишились поза увагою науковців.

Актуалізацію готовності майбутнього вчителя початкової школи до виховання у молодших школярів культури здоров'язбереження розглядаємо у контексті цілісної професійної підготовки як систему теоретично обгрунтованих і прикладних знань студентів щодо сутності культури здоров'язбереження; цілеспрямований, організаційний процес, який характеризується включенням майбутніх педагогів до активної здоров'язбережувальної діяльності; інтегроване утворення особистості; вміння і навички, необхідні для збереження, зміцнення і сприяння здоров'ю; психофізіологічний стан майбутнього педагога, що характеризує позитивну мотивацію, саморегуляцію його поведінки, спрямованої на взаємодію духовного, фізичного, психічного і соціального аспектів здоров'я, ціннісне ставлення як до власного здоров'я, так і до здоров'я школярів, усвідомлення особистої відповідальності. Як кожній системі, їй властива певна структура, що спонукає нас до структурно-компонентного аналізу досліджуваного феномену.

Формування мети статті (постановка завдання): виокремити і проаналізувати окремі аспекти структурно-компонентної характеристики феномену “готовність майбутнього вчителя початкової школи до виховання у молодших школярів культури здоров'язбереження". 


\section{КОМПОНЕНТНО-СТРУКТУРНИЙ АНАЛЗЗ ФЕНОМЕНУ "ГОТОВНІСТЬ МАЙБУТНЬОГО ВЧИТЕЛЯ ПОЧАТКОВОӤ ШКОЛИ ДО ВИХОВАННЯ КУЛЬТУРИ ЗДОРОВ'ЯЗБЕРЕЖЕННЯ МОЛОДШИХ ШКОЛЯРІВ”}

Виклад основного матеріалу дослідження. Суттєвим, на нашу думку, $\epsilon$ розгляд компонентного складу досліджуваного феномену, позаяк “готовність майбутніх учителів початкової школи до виховання у молодших школярів культури здоров'язбереження" ми аналізуємо як систему з певною структурою. При цьому послуговуємося досвідом провідних вітчизняних і зарубіжних учених $[2 ; 7 ; 8]$ щодо змісту та характеристики структурних компонентів здоров'язбережувальної компетентності майбутнього педагога, беручи їх за основу при виокремленні структурних компонентів поняття “готовність майбутнього вчителя початкової школи до виховання у молодших школярів культури здоров'язбереження".

Науково вартісними нам видаються узагальнення Н. Козак щодо визначення у структурі здоров'язбережувальної компетентності трьох компонентів, пов'язаних із відомим гаслом: “Знаю, хочу, можу”. 3 таких позицій компонент, що охоплює уявлення, знання, відомості про предмет дослідження, отримав назву когнітивного, пізнавального, знаннєвого; компонент, який відображає окремі цінності, систему життєвих цінностей, емоції особистості, мотивацію - емоційно-ціннісний, мотиваційний, мотиваційно-ціннісний; компонент, пов'язаний із вчинками, поведінкою - поведінковий, діяльнісно-практичний, діяльнісно-поведінковий тощо [7, 49]. Відповідно, сутність першого компонента (когнітивного) - віддзеркалює сукупність уявлень, знань про себе, здоров'я, здоровий спосіб життя та чинники, що впливають на здоров'я, визначають спосіб життя, значення здоров'я та здорового способу життя для людини; другого (емоційно-ціннісного) - емоції, переживання, почуття, пов'язані зі здоров'ям та здоровим способом життя, місце здоров'я у системі життєвих цінностей особистості; третього (поведінкового) - вчинки і дії, від яких залежить збереження, зміцнення, формування здоров'я або його виснаження.

Заслуговує на увагу думка вчених (Д. Воронін [4], Ю. Шапран та ін.), які, аналізуючи особливості здоров'язбережувальної компетентності студентів, виокремлюють у іï структурі мотиваційний, когнітивний, діяльнісний та особистісний компоненти.

Крізь призму означених наукових позицій у площині структурно-компонентного аналізу виокремлено ключові компоненти готовності майбутнього вчителя початкової школи до виховання у молодших школярів культури здоров'язбереження: мотиваційно-особистісний, когнітивний, операційно-діяльнісний.
При виокремленні мотиваційно-особистісного компонента виходимо $з$ того, що мотиви, на думку В. Сластьоніна, є провідним утворенням у складному синтезі структури мотиваційної сфери, яка забезпечує професійнуготовність учителя $[11,17]$.

Важливим, на нашу думку, є висновок про те, що мотиваційно-ціннісна складова готовності майбутніх учителів початкових класів до здійснення здоров'язбережувальної діяльності, спрямованої на виховання культури здоров'язбереження молодших школярів, відображає наявність позитивної емоційної налаштованості студентів на здоров' язбережувальну діяльність і передбачає формування у майбутніх педагогів активної життєвої та професійної позиції у сфері здоров'язбереження. При цьому конструктивною нам видається система критеріїв професійно-педагогічної спрямованості, запропонована Л.Сливкою [12, 82], а саме: визнання майбутніми учителями людини та iï здоров'я як найвищих цінностей; сформованість внутрішніх індивідуально та соціально значущих мотивів майбутніх педагогів щодо їхньої підготовки до здійснення здоров'язбережувальної діяльності, прагнення до саморозвитку у цій сфері, задоволення від неї; ціннісне ставлення майбутніх педагогів до свого здоров'я як прикладу для наслідування дітьми молодшого шкільного віку.

Зауважимо, що Б. Долинський позитивну мотивацію щодо здійснення педагогічної діяльності та досягнення успіху у професійній діяльності пропонує оцінювати за такими показниками: наявність позитивної мотивації на здійснення педагогічної діяльності; настанова на ціннісне ставлення до здоров'я; мотивація на досягнення успіху в діяльності, спрямованій на формування у молодших школярів здоров'язбережувальних навичок і вмінь $[5,188]$.

Суттєвим для нас $є$ те, що змістовою домінантою особистісної складової мотиваційноособистісного компонента досліджуваного феномену, на думку вчених, виступає сформованість вольових якостей майбутніх педагогів. Так, Ю. Лукашин розглядає вольовий механізм як складний багаторівневий регулятор життєдіяльності людини, результат довготривалої та складної внутрішньої роботи особистості, який характеризує стан готовності, внутрішньої мобілізованості $[9,14]$.

Отже, мотиваційно-особистісний компонент готовності є базисом підготовленості майбутнього вчителя початкової школи до виховання у молодших школярів культури здоров'язбереження у психолого-педагогічній, пізнавальній та особистісній сферах. Він акумулює ціннісно- 


\section{КОМПОНЕНТНО-СТРУКТУРНИЙ АНАЛІЗ ФЕНОМЕНУ "ГОТОВНІСТЬ МАЙБУТНЬОГО ВЧИТЕЛЯ ПОЧАТКОВОЇ ШКОЛИ ДО ВИХОВАННЯ КУЛЬТУРИ ЗДОРОВ'ЯЗБЕРЕЖЕННЯ МОЛОДШИХШКОЛЯРІв”}

смислове самовизначення особистості, мотиваційноціннісне ставлення до власного здоров'язбереження і здоров'язбережувальної професійно-педагогічної діяльності, активізацію вольової сфери особистості. Пізнавальні мотиви представлені у вигляді прагнень до постійного розвитку своїх знань, спрямованості на вивчення теоретичних і методичних проблем здоров'язбережувальної освіти, на оволодіння способами проєктування ситуацій виховання культури здоров'язбереження молодшого школяра. Особистісні мотиви впливають на процес самореалізаціі особистості у процесі підготовки до зазначеної діяльності. Мотиви професійно-творчих досягнень проявляються у вигляді прагнень до вивчення, узагальнення і використання педагогічного досвіду, накопичення методичного матеріалу для вдосконалення здоров'язбережувальної освіти.

Когнітивний компонент віддзеркалює специфіку здоров' язбережувальної компетентності майбутнього вчителя початкової школи, що базується на системі психолого-педагогічних, предметних і спеціальних знань, загальнометодичних і спеціальних методичних знань, розуміння студентами важливості процесу виховання у молодших школярів культури здоров'язбереження. Зауважимо: здоров'язбережувальна компетентність майбутнього вчителя початкової школи як складова його професійної компетентності формується під час навчання у закладі вищої освіти, а згодом розвивається у подальшій професійній діяльності. Вона забезпечує компетентну організацію освітнього середовища початкової школи на основі здоров'язбережувальної діяльності. А відтак, для глибини наукового аналізу вважаємо за необхідне уточнити дефініцію поняття “здоров'язбережувальна компетентність”. За твердженням О. Шатрової, “здоров’язбережувальна компетентність” $€$ інтегральною якістю особистості, що виявляється у загальній здатності й готовності до здоров'язбережувальної діяльності в освітньому середовищі, заснована на інтеграції знань, умінь та досвіду $[13,111]$.

Погоджуємося $з$ думкою О. Югової, яка визначає це поняття як комплекс системних знань і уявлень про позитивні та негативні зміни в стані власного здоров'я й здоров'я навколишніх; уміння складати програму збереження свого здоров'я та дієву програму (або план) збереження здоров'я учнів в умовах навчально-виховного процесу; вміння створювати здоров'язбережувальне освітнє середовище; володіння способами організації діяльності з профілактики здоров'я і здоров'язбереження; володіння освітніми технологіями, що бережуть здоров'я учнів; дослідження ефективності освітнього процесу в питаннях здоров'язбереження, а також здатність організувати й реалізувати діяльність 3 профілактики та здоров'язбереження [15, 215].

Варто звернути увагу на визначення Д. Вороніна, який розкриває здоров'язбережувальну компетентність як інтегральну, динамічну рису особистості, що проявляється у здатності організувати й регулювати здоров'язбережувальну діяльність; адекватно оцінювати свою поведінку, а також вчинки й погляди навколишніх; зберігати й реалізовувати власні здоров'язбережувальні позиції у різних, зокрема, несприятливих умовах, виходячи з особисто усвідомлених та засвоєних моральних норм і принципів, а не за рахунок зовнішніх сил; протистояти тиску, протидіяти впливам, що суперечать внутрішнім настановам, поглядам i переконанням, активно їx перетворювати, самостійно приймати моральні рішення [4, 171].

Завизначенням С. Карабаєвої,здоров'язбережувальна компетентність-цеінтегративнапрофесійно-особистісна характеристика, що визначає готовність i здатність педагога початкової освіти кваліфіковано здійснювати і свідомо перебудовувати діяльність зі здоров'язбереження усіх суб' єктів освітнього процесу в особистісному і професійному аспектах на основі знань, умінь, досвіду, вдосконалення професійно значущих якостей особистості $[6,9]$. Конструктивною вважаємо думку Л. Сливки, що інтерпретує когнітивний компонент як засвоєння студентами сукупності спеціальних і психолого-педагогічних знань, необхідних для розв'язання професійно значущих завдань щодо зміцнення та збереження здоров'я учнів та формування у них здоров'язбережувальної компетентності $[12,82]$.

Суттєвою $є$ позиція Б. Долинського, згідно з якою когнітивний компонент передбачає набуття майбутнім учителем необхідних для здоров'язбереження знань і вмінь. Серед них, зокрема, знання про здоров'я людини (психологічне, соціальне, моральне, духовне, фізичне, професійне); здоров'язбережувальні методики; особливості й умови професійної діяльності, спрямованої на здоров'язбереження дітей; знання щодо способів і методів формування здоров'язбережувальних навичок і вмінь в учнів початкової школи [5, 188].

У руслі викладеного вище правомірно стверджувати, що головним елементом когнітивного компонента $€$ система знань, їх зміст і способи застосування у професійній діяльності. Зауважимо, що ці знання здобуваються у результаті інтеграції навчальних дисциплін та 


\section{КОМПОНЕНТНО-СТРУКТУРНИЙ АНАЛІ ФЕНОМЕНУ 'ГОТОВНІСТЬ МАЙБУТНЬОГО ВЧИТЕЛЯ ПОЧАТКОВОЇ ШКОЛИ ДО ВИХОВАННЯ КУЛЬТУРИ ЗДОРОВ' ЯЗБЕРЕЖЕННЯ МОЛОДШИХ ШКОЛЯРІВ”}

реалізації міжпредметних зв'язків. Як слушно зазначає I. Брехман, “процес формування професійних знань і вмінь майбутнього фахівця, зокрема угалузі здоров'язбереження, характеризується великою кількістю різнопланових зв'язків" [3, 25]. Згідно $з$ науковими розвідками, інтеграція навчальних дисциплін у створенні автономної системи здоров'язбереження $\epsilon$ прогресивним фактором освітньої системи, що самоорганізується $[14,19]$. Переконані, що реалізація когнітивного компонента досліджуваного феномену має відбуватися як на основі знань здоров'язбережувальної педагогіки, так і у результаті створення полісуб'єктної середовищної взаємодії (вчитель - учень - батьки) в умовах початкової школи. Отже, когнітивний компонент готовності майбутнього вчителя початкової школи до виховання культури здоров'язбереження молодших школярів визначається рівнем опанування ним визначеної системи знань для забезпечення практичної реалізації завдань професійної здоров'язбережувальної діяльності майбутнього вчителя початкової школи.

Операціийо-діяльнісний компонент уможливлює безпосереднє розв'язання теоретичних і практичних проблем у сфері готовності майбутнього вчителя початкової школи до здоров'язбережувальної професійної діяльності, спрямованої на виховання культури здоров'язбереження молодших школярів й передбачає сформованість: рефлексивних, комунікативних та організаційних умінь і навичок майбутньої професійно-педагогічної здоров'язбережувальної діяльності; вдосконалення вмінь і навичок у галузі самопізнання, саморозвитку; розуміння творчої природи професійно-педагогічної діяльності та розвиток педагогічної творчості майбутніх учителів початкової школи.

Звертаємо увагу на те, що науковці пропонують оцінювати успішність здоров'язбережувальної професійної діяльності вчителя за такими показниками: наявність організаційнокомунікативних здібностей; уміння організовувати і здійснювати здоров'язбережувальну діяльність; уміння розв'язувати нестандартні педагогічні ситуації, наявність у студентів адекватної реакції на негативні вчинки людей; володіння здоров'язбережувальними методиками, спрямованими на формування здоров'язбережувальних умінь та навичок молодших школярів в освітній діяльності $[10,14]$. Важливою характеристикою операційної складової означеного компонента готовності майбутнього вчителя початкової школи до виховання культури здоров'язбереження молодших школярів $є$ здатність до усвідомленої саморегуляції, самовдосконалення як почуття власної компетентності й ефективності у процесі здоров'язбереження та організації середовища початкової школи на його основі.

Висновки 3 даного дослідження i перспективи подалыших розвідок. Проведений теоретичний аналіз і узагальнення уможливив виокремити компоненти змістової характеристики феномена “готовність майбутніх учителів початкової школи до виховання у молодших школярів культури здоров'язбереження", а саме: мотиваційно-особистісний, когнітивний, операційно-діяльнісний. Вони слугуватимуть підгрунтям для визначення критеріїв, показників, окреслення рівнів сформованості досліджуваного педагогічного явища, що розглядається нами як перспектива подальших наукових розвідок.

\section{ЛІТЕРАТУРА}

1. Баштовенко О. Визначення фізичного розвитку складової здоров'язбереження. Молодь і ринок Щомісячний науково-педагогічний журнал. Дрогобич, 2019. №2 (169). С.123-129.

2. Белікова Н. О. Формування готовності майбутнього фахівця 3 фізичної реабілітації до здоров'язберігаючої діяльності. Оновлення змісту, форм та методів навчання і виховання в закл. освіти : зб. наук.пр. 2008. Вип. 41. С. 28-31.

3. Брехман И. И. Валеология - наука о здоровье. 2-е изд., доп., перераб. Москва, 1990. 186 с.

4. Воронін Д. С. Формування здоров'язберігаючої компетентності студентів вищих навчальних закладів засобами фізичного виховання: дис. ... канд. пед. наук: 13.00.07. Херсон, 2006. $221 \mathrm{c}$.

5. Долинський Б.Т. Теоретико-методичні засади підготовки майбутніх учителів до формування здоров'язбережувальних навичок і вмінь у молодших школярів у навчально-виховній діяльності : монографія. Одеса, 2010.269 с.

6. Карабаева С. И. Совершенствование здоровьесберегающей компетентности педагогв в процесе методической работы в дошкольной организации : автореф. дис. ....канд. пед. наук : 13.00.08. Ульяновск, 2014.26 с.

7. Козак Н. Здоров'язберігаюче виховання підлітків основної школи в навчально-виховному процесі: дис. ... канд. пед. наук: 13.00.07. Полтава, 2016. 240 с.

8. Левінець Н. В. Формування професійної готовності майбутніх вихователів до здійснення фізичного виховання дошкільників на засадах народних традицій: дис ... канд. пед. наук: 13.00.04. Київ, 2006.

9. Лукашин Ю. В. Формирование здоровьесберегающей компетенции у студентов педагогического вуза : автореф. дис. канд. пед. наук: 13.00.08. Пенза, 2010. 23 с.

10. Московченко О.Н. Системний підхід до оцінки здорового способу життя. Валеологія. 1999. № 2. C. $14-18$.

11. Сластенин В. А. Профессиональная готовность учителя к воспитательной работе:содержание, структура функционирования. Профессиональная 


\section{КОМПОНЕНТНО-СТРУКТУРНИЙ АНАЛІЗ ФЕНОМЕНУ "ГОТОВНІСТЬ МАЙБУТНЬОГО ВЧИТЕЛЯ ПОЧАТКОВОЇ ШКОЛИ ДО ВИХОВАННЯ КУЛЬТУРИ ЗДОРОВ'ЯЗБЕРЕЖЕННЯ МОЛОДШИХШКОЛЯРІ””}

подготовка учителя в системе высшего образования. Москва, 1995. С. 14-28.

12. Сливка Л. Деякі аспекти теорії та методики підготовки майбутніх учителів початкових класів до здоров'язберігаючої діяльності. Проблеми підготовки сучасного вчителя: зб. наук.праць. Умань: ППЖовтий О. О., 2014. № 10, Ч. 2. С. $80-86$.

13. Шатрова Е. А. Теоретическая модель формирования здоровьесберегающей компетентности педагога. Вестник ТГПУ (TSPU Bulletin). 2012. № 2(117). C. $111-116$.

14. Харитонов В. И. Совершенствование физического воспитания как ценности здорового образа жизни и здоровья учащихся. Теория и практика физ. культуры. 2002. № 1. С.19-23.

15. Югова Е. А. Анализ структуры и содержания здоровьесберегающей компетенции студентов педагогического вуза. Вестник Красноярского государственного педагогического университета им. В. П. Астафьева. 2011. Т. 1. Психолого-педагогические науки. № 3(17). С. 213-217.

\section{REFERENCES}

1. Bashtovenko, O. (2019). Vyznachennia fizychnoho rozvytku - skladovoi zdoroviazberezhennia [Determining physical development is a component of health]. "Youth and market". Monthly scientific-pedagogical journal. Drogobych,Vol.2 (169), pp. 123-129 [in Ukrainian].

2. Bielikova, N. O. (2008). Formuvannia hotovnosti maibutnoho fakhivtsia z fizychnoi reabilitatsii do zdoroviazberihaiuchoi diialnosti [Formation of readiness of the future specialist in physical rehabilitation for healthpreserving activity]. Updating of the content, forms and methods of teaching and education in educational establishments: coll. of scientific works. Vol. 41, pp. 2831.[in Ukrainian].

3. Brekhman, I. I. (1990). Valeologiya - nauka o zdorove [Valeology is the science of health]. 2nd ed. Moscow,186 p. [in Russian].

4. Voronin, D. Ye.(2006). Formuvanniazdoroviazberihaiuchoi kompetentnosti studentiv vyshchykh navchalnykh zakladiv zasobamy fizychnoho vykhovannia [Formation of healthpreserving competence of students of higher educational institutions by means of physical education]. Candidate's thesis. Kherson, 221 p. [in Ukrainian].

5. Dolynskyi, B.T. (2010). Teoretyko-metodychni zasady pidhotovky maibutnikh uchyteliv do formuvannia zdoroviazberezhuvalnykh navychok i vmin u molodshykh shkoliariv u navchalno-vykhovnii diialnosti [Theoretical and methodical bases of preparation of future teachers for formation of health-preserving skills and abilities at junior schoolboys in educational activity]. Monograph. Odessa, 269 p. [in Ukrainian].

6. Karabaeva, S. I. (2014). Sovershenstvovanie zdorovesberegayushchey kompetentnosti pedagogv v protsese metodicheskoy raboty $\mathrm{v}$ doshkolnoy organizatsii
[Improving the health-preserving competence of teachers in the process of methodological work in a preschool organization]. Extended abstract of candidate's thesis. Ulyanovsk, 26 p. [in Russian].

7. Kozak, N. (2016). Zdoroviazberihaiuche vykhovannia pidlitkiv osnovnoi shkoly $\mathrm{v}$ navchalno-vykhovnomu protsesi [Healthy education of primary school adolescents in the educational process]. Candidate's thesis. Poltava, 240 p. [in Ukrainian].

8. Levinets, N. V. (2006). Formuvannia profesiinoi hotovnosti maibutnikh vykhovateliv do zdiisnennia fizychnoho vykhovannia doshkilnykiv na zasadakh narodnykh tradytsii [Formation of professional readiness of future educators for physical education of preschoolers on the basis of folk traditions].Candidate's thesis. Kyiv. [in Ukrainian].

9.Lukashin, Yu. V.(2010). Formirovaniezdorovesberegayushchey kompetentsii u studentov pedagogicheskogo vuza [Formation of health-preserving competence among students of a pedagogical university]. Extended abstract of candidate's thesis.Penza, 23 p. [in Russian].

10. Moskovchenko, O.N. (1999). Systemnyi pidkhid do otsinky zdorovoho sposobu zhyttia [A systematic approach to assessing a healthy lifestyle]. Valeology. Kyiv. No.2, pp. 14-18. [in Ukrainian].

11. Slastenin, V. A. (1995). Professionalnaya gotovnost uchitelya k vospitatelnoy rabote:soderzhanie, struktura funktsionirovaniya [Teacher's professional readiness for educational work: content, structure of functioning]. Professional training of teachers in the higher education system. Moscow, pp.14-28. [in Russian].

12. Slyvka, L. (2014). Deiaki aspekty teorii ta metodyky pidhotovky maibutnikh uchyteliv pochatkovykh klasiv do zdoroviazberihaiuchoi diialnosti [Some aspects of the theory and methods of preparing future primary school teachers for health activities].Problems of modern teacher training: coll. Science. Uman, no. 10, part. 2. pp. 80-86. [in Ukrainian].

13. Shatrova, E. A. (2012). Teoreticheskaya model formirovaniya zdorovesbe-regayushchey kompetentnosti pedagoga [Theoretical model of formation of healthpreserving competence of the teacher]. TSPU Bulletin. No. (117). pp. 111-116. [in Russian].

14. Kharitonov, V. I. (2002). Sovershenstvovanie fizicheskogo vospitaniya kak tsennosti zdorovogo obraza zhizni i zdorovya uchashchikhsya [Improving physical education as a value for a healthy lifestyle and health of students]. Theory and practice of physical. culture. No. 1.pp. 19-23. [in Russian].

15. Yugova, E. A. (2011). Analiz struktury i soderzhaniya zdorovesberegayushchey kompetentsii studentov pedagogicheskogo vuza [Analysis of the structure and content of health-preserving competence of students of a pedagogical university]. Bulletin of the Krasnoyarsk State Pedagogical University V.P. Astafieva. Vol. 1. Psychological and pedagogical sciences. No. 3 (17). pp. 213-217. [in Russian].

Стаття надійшла до редакції 28.10.2020

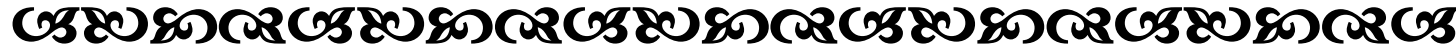

